Check for updates

Cite this: RSC Adv., 2018, 8, 12944

Received 27th February 2018

Accepted 19th March 2018

DOI: 10.1039/c8ra01752b

rsc.li/rsc-advances

\section{Epitaxial growth of ultrathin layers on the surface of sub-10 nm nanoparticles: the case of $\beta-\mathrm{NaGdF}_{4}: \mathrm{Yb} /$ Er@NaDyF 4 nanoparticles}

\author{
Yang Su, $\dagger^{\mathrm{a}} \mathrm{Li}-\mathrm{Na} \mathrm{Hao}, \dagger^{\mathrm{b}}$ Kun Liu, ${ }^{\mathrm{b}}$ Jun Zhang, ${ }^{\mathrm{c}}$ Liang Dong, ${ }^{* d}$ Yunjun Xu, ${ }^{\mathrm{e}}$ \\ Yang Lu (iD *a and Hai-Sheng Qian (D)*b
}

\begin{abstract}
Upconversion core-shell nanoparticles have attracted a large amount of attention due to their multifunctionality and specific applications. In this work, based on a NaGdF 4 sub-10 nm ultrasmall nanocore, a series of core-shell upconversion nanoparticles with uniform size doped with $\mathrm{Yb}^{3+}, \mathrm{Er}^{3+}$ and $\mathrm{NaDyF}_{4}$ shells with different thicknesses were synthesized by a facile sequential growth process. $\mathrm{NaDyF}_{4}$ coated upconversion luminescent nanoparticles showed an obvious fluorescence quenching under excitation at $980 \mathrm{~nm}$ as a result of energy resonance transfer between $\mathrm{Yb}^{3+}, \mathrm{Er}^{3+}$ and $\mathrm{Dy}^{3+} . \mathrm{NaGdF}_{4}: \mathrm{Yb}^{3}, \mathrm{EraNaDyF}_{4}$ core-shell nanoparticles with ultrathin layer shells exhibited a better $T_{1}$-weighted MR contrast.
\end{abstract}

\section{Introduction}

In recent years, core-shell nanoparticles with controllable sizes and shapes have attracted a great deal of interest because of their diverse applicability. ${ }^{\mathbf{1 - 4}}$ Lanthanide-doped upconversion nanoparticles (UCNPs) have been studied widely due to their broad applications in energy and biological areas, such as biomedical imaging, solar energy conversion and photocatalysis. $^{5-13}$ There are known methods for synthesizing coreshell nanoparticles with well-controlled sizes, shapes and nanostructures, which lead to enhanced performance. ${ }^{\mathbf{1 4 - 1 7}}$ Most of these upconversion nanocrystals have been fabricated by a seed-mediated growth process, which is more complex and time-wasting. Moreover, various organic solvents were necessary. Recent reports indicate that the core-shell nanoparticles synthesized by the seed-mediated heat-up method were less likely to form a uniform shell, and the nanosized cores were only partially covered by a shell. ${ }^{18,19}$ Recently, with a highboiling-point oleic complex serving as a shell precursor, a successive one-pot layer-by-layer (SLBL) technique has been developed to fabricate high-quality monodispersed core-shell

${ }^{a}$ Department of Chemistry, Hefei University of Technology, Hefei 230009, P. R. China. E-mail: yanglu@hfut.edu.cn

${ }^{b}$ Department of Medical Materials and Rehabilitation Engineering, School of Medical Engineering, Hefei University of Technology, Hefei 230009, P. R. China. E-mail: shqian@hfut.edu.cn; Tel: +8655162901285

${ }^{c}$ Analytical and Testing Center, Hefei University of Technology, Hefei 230009, P. R. China

${ }^{d}$ Hefei National Laboratory for Physical Sciences at the Microscale, University of Science and Technology of China, Hefei 230026, P. R. China. E-mail: dldisc@ustc. edu.cn

${ }^{e}$ Department of Radiology, Anhui Provincial Hospital, Hefei 230001, P. R. China

$\dagger$ These authors contributed equally to this work.
$\mathrm{NaGdF}_{4}: \mathrm{Yb}, \mathrm{Er} @ \mathrm{NaYF}_{4}$ upconversion nanoparticles. ${ }^{20}$ However, the synthesis of uniform ultrathin layers on the surface of sub$10 \mathrm{~nm}$ nanoparticles is still a challenge.

The fluorescence intensity of the core-shell structured upconversion nanoparticles was much stronger than the single core, because the shell can make up for the surface defect of the core. ${ }^{21-23}$ As an example, $\mathrm{NaYF}_{4}: \mathrm{Yb}, \mathrm{Tm} @ \mathrm{NaYF}_{4}: \mathrm{Yb}, \mathrm{Er}$ nanocrystals exhibited a remarkable enhancement in fluorescence intensity. ${ }^{24}$ With the introduction of an inert shell, ultrasmall $\mathrm{LaF}_{3}: \mathrm{Yb}^{3+} / \mathrm{Ln}^{3+}(\mathrm{Ln}=\mathrm{Er}, \mathrm{Tm}$, and Ho)@LaF 3 core-shell nanoparticles exhibited a maximum 9 times enhancement of upconversion intensity compared with single nanocores. ${ }^{16}$ In general, lanthanide-doped upconversion nanoparticles $\mathrm{NaGdF}_{4}: \mathrm{Yb}$,Er can emit visible light based on energy transfer under the excitation of a laser. ${ }^{25}$ As the main sensitizer, $\mathrm{Yb}^{3+}$ was excited by $980 \mathrm{~nm}$ photons and jumped from the ground state to the excited state $\left({ }^{2} \mathrm{~F}_{5 / 2}\right)$, then jumped back to the ground state. The transition energy was then transferred to $\mathrm{Er}^{3+}$, which was excited from the ground level to an excited one. Subsequently, green emission at $522 \mathrm{~nm}$ and $547 \mathrm{~nm}$ ensues due to electrons in the excited state relaxing nonradiatively to lower-energy states $\left({ }^{2} \mathrm{H}_{11 / 2} \rightarrow{ }^{4} \mathrm{I}_{5 / 2}\right.$ and $\left.{ }^{4} \mathrm{~S}_{3 / 2} \rightarrow{ }^{4} \mathrm{I} 1_{5 / 2}\right) .{ }^{26}$ The core-shell structure of $\mathrm{NaGdF}_{4}: \mathrm{Yb}, \mathrm{Er} @ \mathrm{NaGdF}_{4}$ nanoparticles showed a significant fluorescence enhancement. ${ }^{27}$ Nevertheless, $\mathrm{NaDyF}_{4}$ coated $\mathrm{NaGdF}_{4}: \mathrm{Yb}, \mathrm{Er}$ nanoparticles presented an opposite result because $\mathrm{Dy}^{3+}$ is known as a quencher of the upconversion luminescence of $\mathrm{Er}^{3+} \cdot{ }^{28}$ But there has been very little exploration into the $\mathrm{Dy}^{3+}$ quenching mechanism.

Magnetic resonance (MR) imaging is a useful invasive diagnostic technique used in clinical medicine. In order to enhance the contrast of the pathological region and diagnostic sensitivity, contrast agents (CAs) are frequently employed in MR diagnosis, and there are two kinds of MR contrast agents: 
positive $\left(T_{1}\right)$ CAs and negative $\left(T_{2}\right)$ CAs. ${ }^{29-34}$ The longitudinal relaxation time of the surrounding water protons could be effectively shortened by $T_{1}$-weighted CAs (mostly paramagnetic $\mathrm{Gd}^{3+}$ chelates, such as Gd-DTPA), resulting in a brighter signal. The transverse relaxation time could be decreased by $T_{2}$ weighted CAs (mostly superparamagnetic iron oxide (SPIO) nanoparticles), leading to a darker signal. In the clinic, most commercial contrast agents are gadolinium based contrast agents (GBCAs), because the brightened signals produced by GBCAs in the $T_{1}$-weighted images of lesions are easily identified by clinicians. Due to the poor physiological stability of linear GBCAs, ${ }^{35,36}$ and their relative side-effects such as nephrogenic systemic fibrosis (NSF) in kidney patients, ${ }^{37,38}$ more efforts have been recently suggested for the development of GBCAs with a higher relaxivity and better thermodynamic stability. Very recently, ultrasmall sized $\mathrm{NaGdF}_{4}$ nanocrystals have exhibited great promise to serve as stable $T_{1} \mathrm{~W}$ MR contrast agents with a high $T_{1} \mathrm{w}$ relaxivity and negligible leakage of free gadolinium ions. ${ }^{39-42}$ When the ultrasmall sized NaGdF4 nanocrystals serve as a core to fabricate core-shell structured nanocomposites, it's reasonable that the $T_{1} \mathrm{~W}$ MR contrast performance should be affected due to the change in surface properties and less interaction with the surrounding protons. However, this remains unexplored.

Herein, a facile sequential growth process has been used to synthesize $\mathrm{NaGdF}_{4}: \mathrm{Yb}, \mathrm{Er} @ \mathrm{NaDyF}_{4}$ core-shell nanoparticles with different shell thicknesses. $\mathrm{NaGdF}_{4}: \mathrm{Yb}, \mathrm{Er} @ \mathrm{NaDyF}_{4}-1$ with ultrathin shells exhibited a higher longitudinal relaxivity $\left(r_{1}\right)$ than $\mathrm{NaGdF}_{4}: \mathrm{Yb}, \mathrm{Er} @ \mathrm{NaDyF}_{4}-2$, which is a promising $T_{1}$ magnetic resonance imaging agent. In addition, the cause of the decrease in upconversion fluorescence intensity of the $\mathrm{NaDyF}_{4}$ coated $\mathrm{NaGdF}_{4}: \mathrm{Yb}$,Er was illustrated, which provides guidance for subsequent research into upconversion luminescent materials with core-shell structures.

\section{Experimental section}

\section{Reagents and materials}

$\mathrm{DyCl}_{3} \cdot 6 \mathrm{H}_{2} \mathrm{O}(99.99), \quad \mathrm{GdCl}_{3} \cdot 6 \mathrm{H}_{2} \mathrm{O} \quad(99.99 \%), \quad \mathrm{YbCl}_{3} \cdot 6 \mathrm{H}_{2} \mathrm{O}$ (99.99\%) and $\mathrm{ErCl}_{3} \cdot 6 \mathrm{H}_{2} \mathrm{O}(99.99 \%)$, sodium hydroxide $(\mathrm{NaOH})$, ammonium fluoride $\left(\mathrm{NH}_{4} \mathrm{~F}\right)$, oleic acid (OA, 90\%) and 1-octadecene (ODE, 90\%) were purchased from Aladdin Chemical Reagent Corporation (Shanghai, China). Organic reagents including methanol, cyclohexane and ethanol were purchased from Sinopharm Chemical Reagent Corporation (Shanghai, China). HepG2 cells were purchased from the Shanghai Institute of Cell Bank.

\section{Synthesis of Gd/Yb/Er-oleic and Dy-oleic complexes}

$195 \mathrm{mmol} \mathrm{GdCl}_{3}, 0.05 \mathrm{mmol} \mathrm{YbCl}_{3}, 0.005 \mathrm{mmol} \mathrm{ErCl}_{3}$ and $3 \mathrm{~mL}$ of OA were added into a $50 \mathrm{~mL}$ three-neck flask then heated to $100{ }^{\circ} \mathrm{C}$ and kept at this temperature for 20 minutes to remove the water during crystallization. The mixture was continuously stirred and heated for 20 minutes to form a clear solution $(\mathrm{Gd} /$ Yb/Er-OA complex). The Dy-oleic complex was prepared by a similar process using $\mathrm{DyCl}_{3}(0.125 \mathrm{mmol})$ and $\mathrm{OA}(3 \mathrm{~mL})$. The
Gd/Yb/Er-oleic and Dy-oleic complex solutions were stable, and were used as precursors of further reactions.

\section{Synthesis of $\mathrm{NaGdF}_{4}: \mathrm{Yb}, \mathrm{Er} @ \mathrm{NaDyF}_{4}$ core-shell nanoparticles with various shell thicknesses}

In a typical experiment, $\mathrm{NaGdF}_{4}: \mathrm{Yb}, \mathrm{Er} @ \mathrm{NaDyF}_{4}$ core-shell nanoparticles were synthesized on the basis of a reported method with some changes. ${ }^{43} 6 \mathrm{~mL}$ OA and $15 \mathrm{~mL}$ ODE were added into a three-neck reaction flask, and a clear methanol solution $(10 \mathrm{~mL})$ containing $1.5 \mathrm{mmol}$ of $\mathrm{NaOH}$ and $2 \mathrm{mmol}$ of $\mathrm{NH}_{4} \mathrm{~F}$ were added into the flask with vigorous stirring. Then the solution was slowly heated to $100{ }^{\circ} \mathrm{C}$ to remove methanol and water. After the water and oxygen was removed under vacuum with continuous stirring, the solution was heated to $280{ }^{\circ} \mathrm{C}$ slowly under an argon atmosphere. Then the Gd/Yb/Er-OA complex $(0.25 \mathrm{mmol})$ precursor solution was injected into the reaction system quickly at $280{ }^{\circ} \mathrm{C}$ and maintained at this temperature for $60 \mathrm{~min}$. The reaction solution was allowed to cool to room temperature then $0.125 \mathrm{mmol}$ of the Dy-OA complex was injected rapidly into the reaction mixture at room temperature and the solution was heated to $280{ }^{\circ} \mathrm{C}$ for another $60 \mathrm{~min}$ to obtain the $\mathrm{NaGdF}_{4}: \mathrm{Yb}, \mathrm{Er} @ \mathrm{NaDyF}_{4}-1$ with ultrathin shells. Finally, the solution was cooled down to room temperature naturally and the resulting nanoparticles were precipitated by the addition of ethanol, collected by centrifugation and then redispersed in cyclohexane.

$\mathrm{NaGdF}_{4}: \mathrm{Yb}, \mathrm{Er} @ \mathrm{NaDyF}_{4}-2$ nanoparticles with different shell thicknesses were synthesized using the same process as for the abovementioned nanoparticles, except for one thing: after the first Dy-OA (0.125 mmol) compound was injected and incubated for 60 minutes, the reaction system was reduced to room temperature and $0.125 \mathrm{mmol}$ of the Dy-OA complex was injected again, and kept at $280{ }^{\circ} \mathrm{C}$ for an additional $1 \mathrm{~h}$.

\section{Surface modification}

The hydrophobic $\mathrm{NaGdF}_{4}: \mathrm{Yb}, \mathrm{Er} @ \mathrm{NaDyF}_{4}$ nanoparticles covered with oleic acid were transferred to the aqueous phase using a ligand-exchange method. ${ }^{23} \quad \mathrm{NaGdF}_{4}: \mathrm{Yb}, \mathrm{Er} @ \mathrm{NaDyF}_{4}$ cyclohexane solution (10 $\mathrm{mg} \mathrm{mL}^{-1} 10 \mathrm{~mL}$ ) was dropwise added to $10 \mathrm{~mL}$ of PEG-PAA in 1,4-dioxane $\left(10 \mathrm{mg} \mathrm{mL}^{-1}\right)$ and stirred for 12 hours at room temperature. Then the mixed solution was naturally cooled down to room temperature after removing the cyclohexane at $80{ }^{\circ} \mathrm{C}$. The resulting solution was collected by centrifugation and washed with water three times. The final hydrophilic nanoparticles were dispersed in water for further use.

\section{MR measurement}

Various concentrations of the PEG-PAA modified $\mathrm{NaGdF}_{4}$ :$\mathrm{Yb}, \mathrm{Er} @ \mathrm{NaDyF}_{4}$ and $\mathrm{NaGdF}_{4}: \mathrm{Yb}, \mathrm{Er} @ \mathrm{NaDyF}_{4} @ \mathrm{NaDyF}_{4}$ nanoparticles dispersed in deionized water were prepared, and their $T_{1}$ weighted MR images were acquired on a Siemens 3.0 Tesla MR scanner using the inversion recovery (IR) sequence. The imaging parameters were as follows: repetition time $\left(T_{\mathrm{R}}\right)=4000$ ms, echo time $\left(T_{\mathrm{E}}\right)=10.88 \mathrm{~ms}$, and a series of inversion times $\left(T_{\mathrm{I}}\right)$ between 50 and $3500 \mathrm{~ms}$ were employed. The field of view 
$(\mathrm{FOV})=220 \times 220 \mathrm{~mm}^{2}$. Then the $T_{1}$ values of each sample at different concentrations were calculated on a workstation to obtain the relaxivity.

\section{Characterization}

Transmission electron microscopy (TEM) analysis was carried out on a JEM-2100F (JEOL, Japan) transmission electron microscope. The phase of the as-prepared product was characterized by X-ray powder diffraction (XRD) analysis, which was performed on a Philips X'Pert PRO SUPER X-ray diffractometer equipped with graphite monochromated $\mathrm{Cu} \mathrm{K} \alpha$ radiation, and the operation voltage and current were maintained at $40 \mathrm{kV}$ and $40 \mathrm{~mA}$, respectively. The upconversion fluorescence spectra were measured on an F-2700 fluorescence spectrometer (Hitachi High-Technology Corporation), where an external CW laser at $980 \mathrm{~nm}$ replaced the xenon lamp as the excitation source. Inductively coupled plasma atomic emission spectroscopy (ICPAES) was employed to determine the concentration of $\mathrm{Gd}^{3+}$ in the solutions. FT-IR spectra were measured on a Bruker Vector22 FT-IR spectrometer. The relaxivity measurements were carried out on a clinical MRI instrument (Siemens Trio Tim 3.0 $\mathrm{T}$, Germany).

\section{Results and discussion}

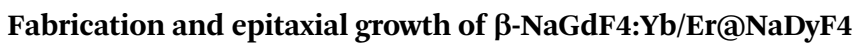
nanoparticles with an ultrathin layer

The synthesis of $\mathrm{NaGdF}_{4}: \mathrm{Yb} / \mathrm{Er} @ \mathrm{NaDyF}_{4}$ core-shell nanoparticles with different shell thicknesses was achieved by a sequential growth process (Fig. 1). $\mathrm{NaGdF}_{4}: \mathrm{Yb}, \mathrm{Er}$ nanoparticles were first synthesized at $280{ }^{\circ} \mathrm{C}$ in the presence of sodium hydroxide, ammonium fluoride and $\mathrm{Gd} / \mathrm{Yb} / \mathrm{Er}-\mathrm{OA}$ complexes.

When the reaction system containing $\mathrm{NaGdF}_{4}$ :Yb,Er nanoparticles was reduced to room temperature, the Dy-OA $(0.125$ $\mathrm{mmol}$ ) complex was injected, the solution was then heated to $280{ }^{\circ} \mathrm{C}$ and kept for one hour to obtain $\mathrm{NaGdF}_{4}: \mathrm{Yb} / \mathrm{Er} @ \mathrm{NaDyF}_{4}{ }^{-}$ 1. Afterwards, another $0.125 \mathrm{mmol}$ Dy-OA complex was injected quickly to the reaction system to synthesize the $\mathrm{NaGdF}_{4}$ :$\mathrm{Yb}, \mathrm{Er} @ \mathrm{NaDyF}_{4}-2$. Finally, $\mathrm{NaGdF}_{4}: \mathrm{Yb}, \mathrm{Er} @ \mathrm{NaDyF}_{4}$ core-shell nanoparticles with different shell thicknesses could be obtained.
The crystallographic structures of the as-prepared $\mathrm{NaGdF}_{4}$ :Yb,Er@NaDyF ${ }_{4}$ nanoparticles were studied by X-ray powder diffraction (XRD) (Fig. 2). All of the identified diffraction peaks for the core-shell nanoparticles in the XRD pattern were in accordance with the data for the reference hexagonal phase of NaGdF4 (JCPDS card no. 27-0699). No impurity crystalline phase was found in the diffraction pattern. The broadening of the diffraction peaks ascribed to OA-coated nanoparticles distinctly indicated the property of nanocrystallinity. Therefore, the XRD pattern revealed that the composition of OA-coated nanoparticles is very pure.

Transmission electron microscopy (TEM) was used to study the structures and morphology of the as-synthesized nanoparticles (Fig. 3a-c). The $\mathrm{NaGdF}_{4}$ : $\mathrm{Yb}$,Er nanoparticles with a uniform size of about $9.5 \mathrm{~nm}$ (Fig. 3a and d) are monodispersed well. After the $\mathrm{NaGdF}_{4}: \mathrm{Yb}$,Er cores were coated by $\mathrm{NaDyF}_{4}$ shells, the diameters of the nanoparticles were distributed mainly at about $11.5 \mathrm{~nm}$. The thickness of the NaDyF4 shell was about $1 \mathrm{~nm}$ (Fig. 3b and e). After further growth of $\mathrm{NaDyF}_{4}$ shells on the surface of $\mathrm{NaGdF}_{4}$ :$\mathrm{Yb}$,Er@NaDyF $\mathrm{N}_{4}-1$, the monodisperse nanoparticles exhibited an average size of $13.5 \mathrm{~nm}$, indicating that $\mathrm{NaDyF}_{4}$ nanocrystals with about $2 \mathrm{~nm}$ shell thickness were grown on the surface of $\mathrm{NaGdF}_{4}: \mathrm{Yb}$,Er nanocores (Fig. 3c and f).

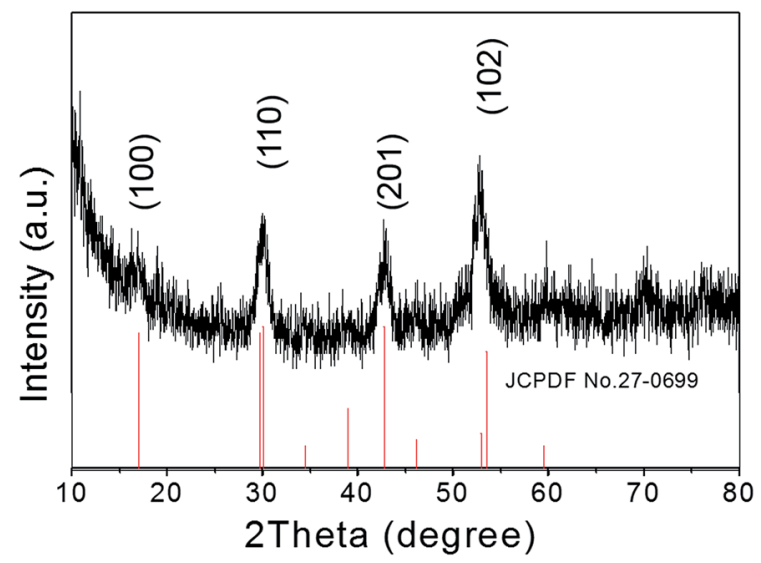

Fig. 2 X-ray diffraction patterns of $\mathrm{NaGdF}_{4}: \mathrm{Yb}_{\text {, Er@NaDyF}}$ nanoparticles.

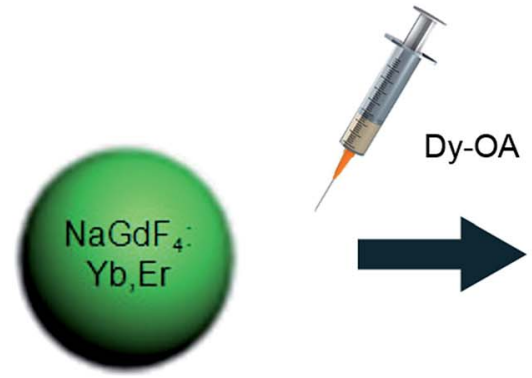

Sub-10 nm
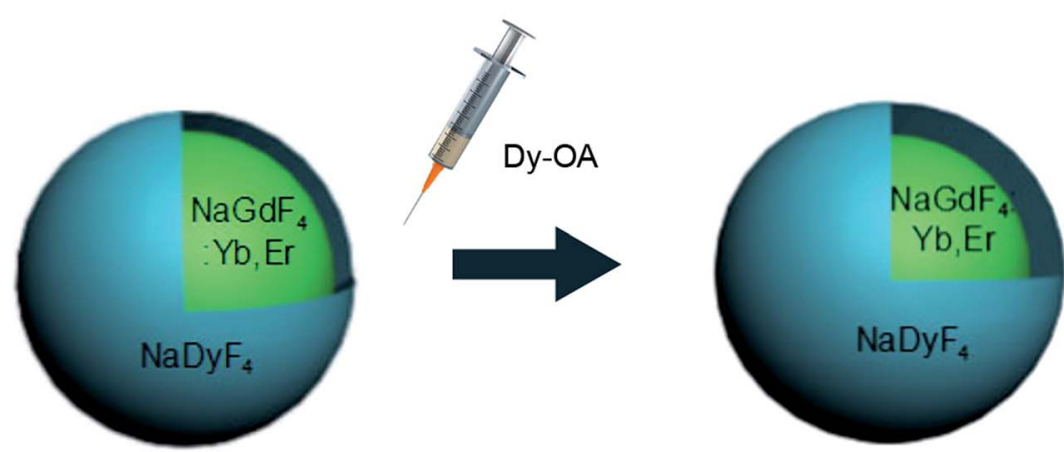

Fig. 1 A schematic illustration of the epitaxial growth of $\mathrm{NaGdF}_{4}: \mathrm{Yb}_{\text {Er }} @ \mathrm{NaDyF}_{4}$ nanoparticles with different shell thicknesses. 

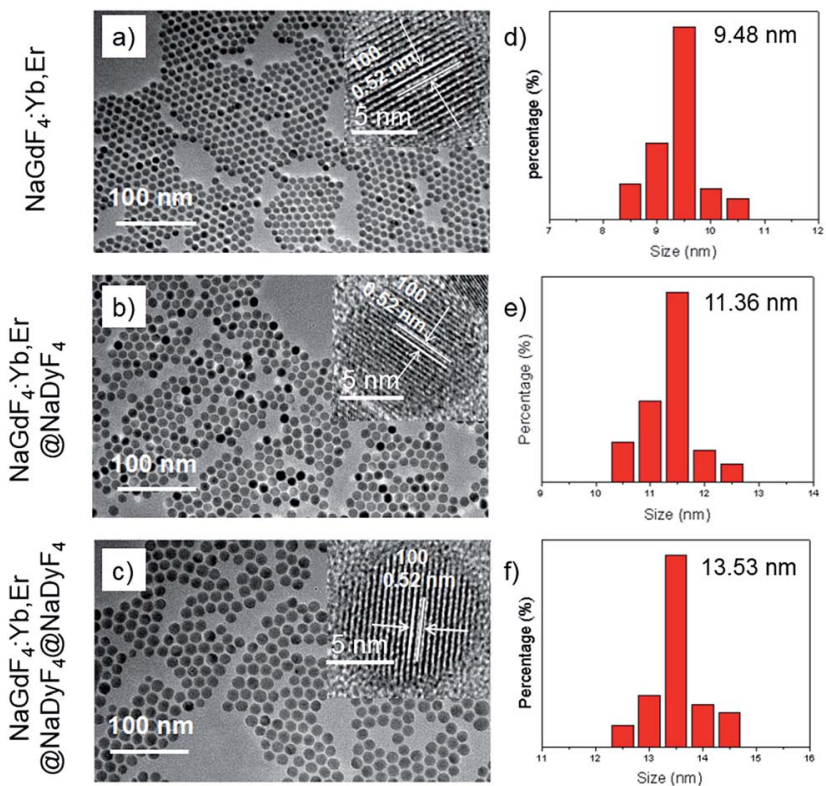

Fig. 3 TEM images and the size distribution of ( $a$ and d) $\mathrm{NaGdF}_{4}: \mathrm{Yb}, \mathrm{Er}$, (b and e) $\mathrm{NaGdF}_{4}: \mathrm{Yb}, \mathrm{EraNaDyF}_{4}-1$ and (c and f) $\mathrm{NaGdF}_{4}$ :$\mathrm{Yb}, \mathrm{Er} \mathrm{aNaDyF} \mathrm{N}_{4}-2$. The insets of $(\mathrm{a}-\mathrm{c})$ are HR-TEM images of the above three nanoparticles and the scale bars correspond to $5 \mathrm{~nm}$.

As shown in the insets of Fig. 3a-c, the high-resolution transmission electron microscopy (HR-TEM) images taken of the enlarged single nanoparticles of the above three samples proved that the nanoparticles had high crystallinity with a lattice spacing of $0.52 \mathrm{~nm}$, which was consistent with the (100)

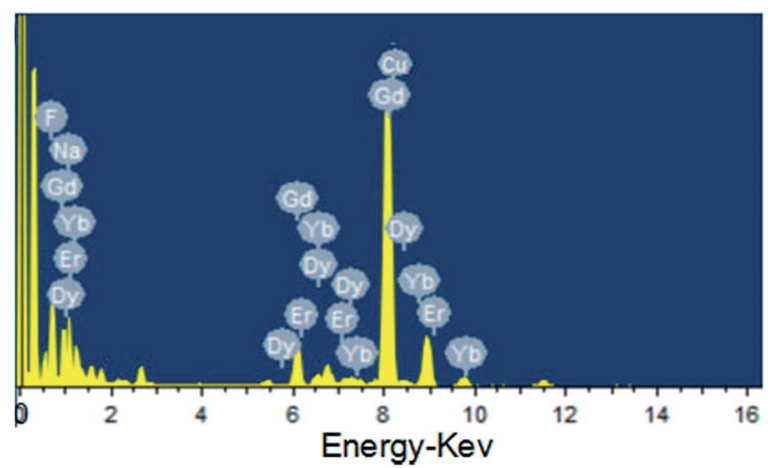

Fig. 5 The energy dispersive $X$-ray analysis (EDX) of the as-prepared $\mathrm{NaGdF}_{4}: \mathrm{Yb}, \mathrm{Er} @ \mathrm{NaDyF}_{4}$ nanoparticles.

Table 1 The element composition of the as-prepared $\mathrm{NaGdF}_{4}$ :$\mathrm{Yb}$, Er@NaDyF${ }_{4}$ core-shell nanoparticles from EDX analyses

\begin{tabular}{llc}
\hline Element & Weight\% & Atomic\% \\
\hline $\mathrm{F}$ & 23.62 & 60.45 \\
$\mathrm{Na}$ & 9.06 & 19.17 \\
$\mathrm{Gd}$ & 42.15 & 13.03 \\
$\mathrm{Dy}$ & 15.22 & 4.55 \\
$\mathrm{Er}$ & 0.00 & 0.00 \\
Yb & 9.94 & 2.79 \\
Totals & 100 & \\
\end{tabular}

plane of the $\mathrm{NaGdF}_{4}$ nanoparticles. Fig. 4a shows a scanning transmission electron microscopy image of the as-prepared $\mathrm{NaGdF}_{4}: \mathrm{Yb}, \mathrm{Er} @ \mathrm{NaDyF}_{4}$ nanocrystals. The elemental mapping
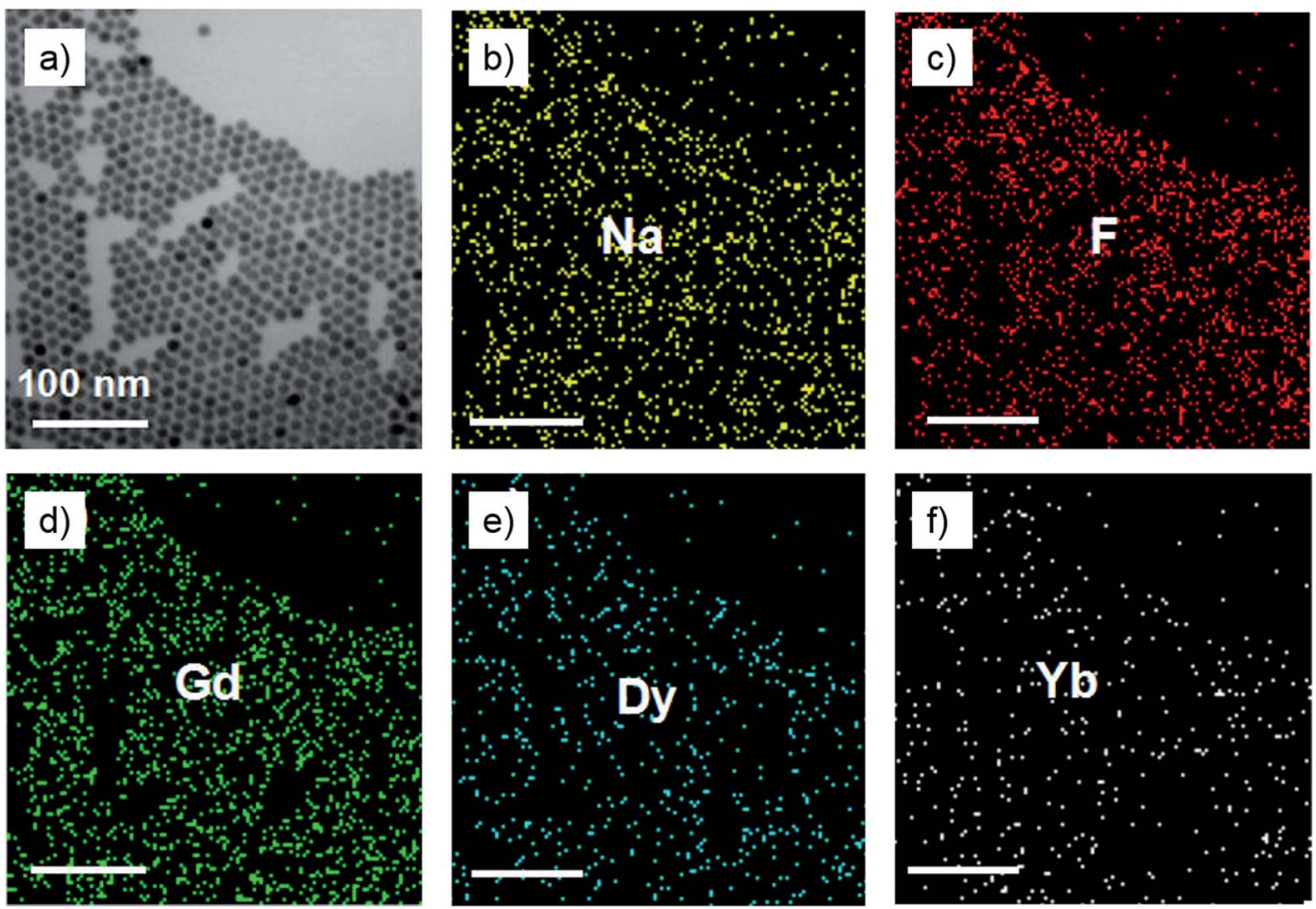

Fig. 4 (a) A scanning transmission electron microscopy (STEM) image of the as-prepared core-shell nanoparticles of $\mathrm{NaGdF}_{4}: \mathrm{Yb} \mathrm{Er}_{\mathrm{aNaDyF}}$. (b-f) Elemental mapping images of $\mathrm{Na}, \mathrm{F}, \mathrm{Gd}$, Dy and $\mathrm{Yb}$ for the STEM image, respectively. 

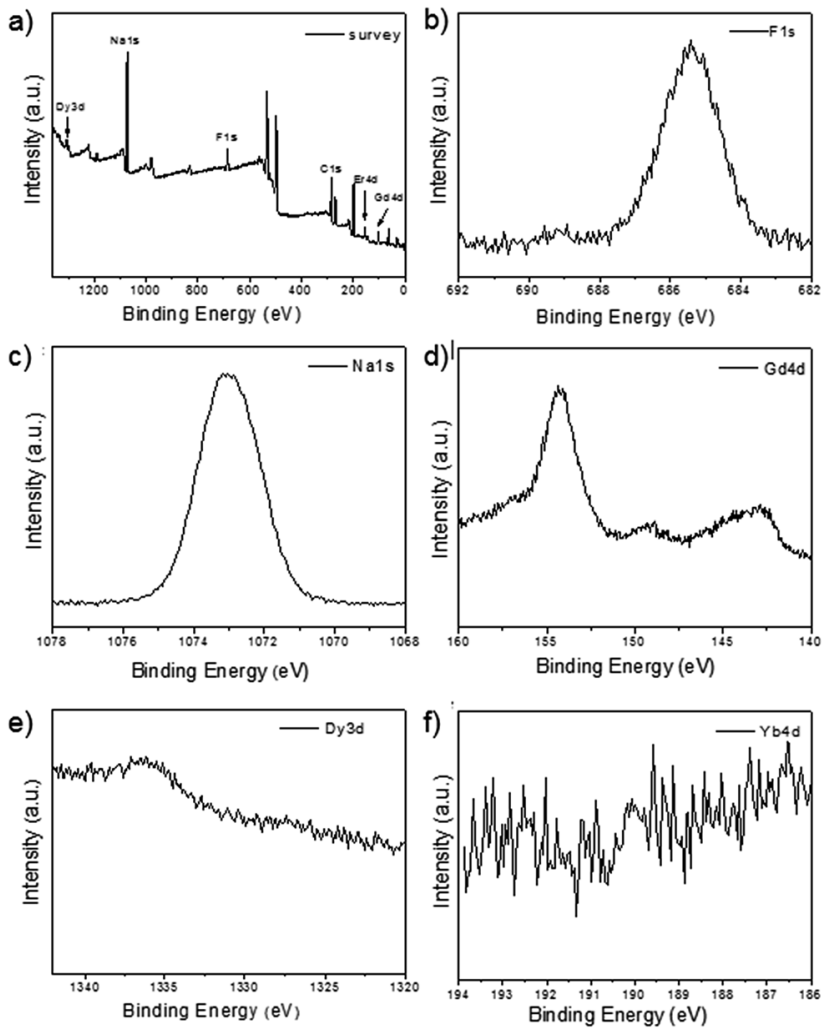

Fig. 6 The $\mathrm{X}$-ray photoelectron spectroscopy (XPS) analysis of $\mathrm{NaYF}_{4}: \mathrm{Yb}_{\mathrm{E}}$ EraNaGdF 4 . (a) The survey spectrum; (b) F 1s; (c) Na 1s; (d) Gd 4d; (e) Dy 3d; (f) Yb 4d.

images for Na, F, Gd, Dy and Yb are shown in Fig. 4b-f, indicating the co-existence of these elements in the as-prepared nanoparticles of $\mathrm{NaGdF}_{4}: \mathrm{Yb}, \mathrm{Er} @ \mathrm{NaDyF}_{4}$. As shown in Fig. 5, energy dispersive $\mathrm{X}$-ray analysis proved the co-existence of $\mathrm{Na}, \mathrm{F}$, $\mathrm{Gd}$, Dy and $\mathrm{Yb}$ in the as-synthesized nanoparticles, and the calculated chemical composition has been shown in Table 1.
The survey scan X-ray photoelectron spectroscopy (XPS) spectrum, as shown in Fig. 6, of the core-shell nanoparticles showed photoelectron lines at binding energies of about $100 \mathrm{eV}, 710 \mathrm{eV}$, $1080 \mathrm{eV}$, and $1300 \mathrm{eV}$, attributed to Gd 4d, F 1s, Na 1s, and Dy $3 \mathrm{~d}$, respectively. This is in good agreement with the results of the elemental mapping and EDX. All of these results indicated that the core-shell nanoparticles of $\mathrm{NaGdF}_{4}: \mathrm{Yb}, \mathrm{Er}$ @NaDyF 4 have been synthesized successfully.

\section{UC fluorescence of $\beta$-NaGdF4:Yb/Er@NaDyF4 nanoparticles with an ultrathin layer}

Fig. 7a shows the UC emission spectra of the different nanoparticles excited at $980 \mathrm{~nm}$. The UC fluorescence peaks are located at 520, 540 and $656 \mathrm{~nm}$, and were assigned to the transitions from ${ }^{2} \mathrm{H}_{11 / 2},{ }^{4} \mathrm{~S}_{3 / 2}$, and ${ }^{4} \mathrm{~F}_{9 / 2}$ to ${ }^{4} \mathrm{I}_{15 / 2}$ of Er, respectively. ${ }^{44}$ The presence of $\mathrm{Dy}^{3+}$ in the shell has shown an obvious influence on the UC luminescence intensity, with the luminescence intensity of $\mathrm{NaGdF}_{4}: \mathrm{Yb}, \mathrm{Er}-1$ and $\mathrm{NaGdF}_{4}$ :$\mathrm{Yb}, \mathrm{Er} @ \mathrm{NaDyF}_{4}-2$ being much lower than that of $\mathrm{NaGdF}_{4}: \mathrm{Yb}, \mathrm{Er}$. In contrast, the luminescence intensity of $\mathrm{NaGdF}_{4}$ :$\mathrm{Yb}$,Er@NaGdF 4 was investigated as well, and was much stronger than that of $\mathrm{NaGdF}_{4}: \mathrm{Yb}, \mathrm{Er} @ \mathrm{NaDyF}_{4}$. The result indicated that the presence of $\mathrm{Dy}^{3+}$ in the shell induced a noticeable quenching of $\mathrm{Er}^{3+}$ luminescence.

One explanation for the $\mathrm{Dy}^{3+}$ quenching of $\mathrm{Er}^{3+}$ luminescence is the depopulation of ${ }^{4} \mathrm{I}_{11 / 2}\left(\mathrm{Er}^{3+}\right)$ and ${ }^{2} \mathrm{~F}_{5 / 2}\left(\mathrm{Yb}^{3+}\right)$ by $\mathrm{Dy}^{3+} \cdot{ }^{45}$ The energy transfer between $\mathrm{Dy}^{3+}, \mathrm{Yb}^{3+}$, and $\mathrm{Er}^{3+}$ can readily occur as the result of the ${ }^{6} \mathrm{H}_{5 / 2} \rightarrow{ }^{6} \mathrm{H}_{15 / 2}$ transition of $\mathrm{Dy}^{3+}$, which is resonant with the ${ }^{2} \mathrm{~F}_{5 / 2} \rightarrow{ }^{2} \mathrm{~F}_{7 / 2}$ transition of $\mathrm{Yb}^{3+}$ ions and the ${ }^{4} \mathrm{I}_{11 / 2} \rightarrow{ }^{4} \mathrm{I}_{15 / 2}$ transition of $\mathrm{Er}^{3+}$ ions (Fig. 7b). Dy ${ }^{3+}$ can be excited by $980 \mathrm{~nm}$ photons from the ${ }^{6} \mathrm{H}_{15 / 2}$ ground state to the ${ }^{6} \mathrm{H}_{5 / 2}$ excited state or receive the energy from excited $\mathrm{Yb}^{3+}$ and $\mathrm{Er}^{3+}$ ions. The life time of ${ }^{6} \mathrm{H}_{5 / 2}$ is short, and the back-energy transfer to $\mathrm{Yb}^{3+}$ is so little that it can be neglected. ${ }^{\mathbf{4 6 , 4 7}}$ The excited $\mathrm{Dy}^{3+}$ can relax radiatively to the ground state, and divert some energy to $\mathrm{Er}^{3+}$ to cause $\mathrm{Er}^{3+}$ excitation from the ground
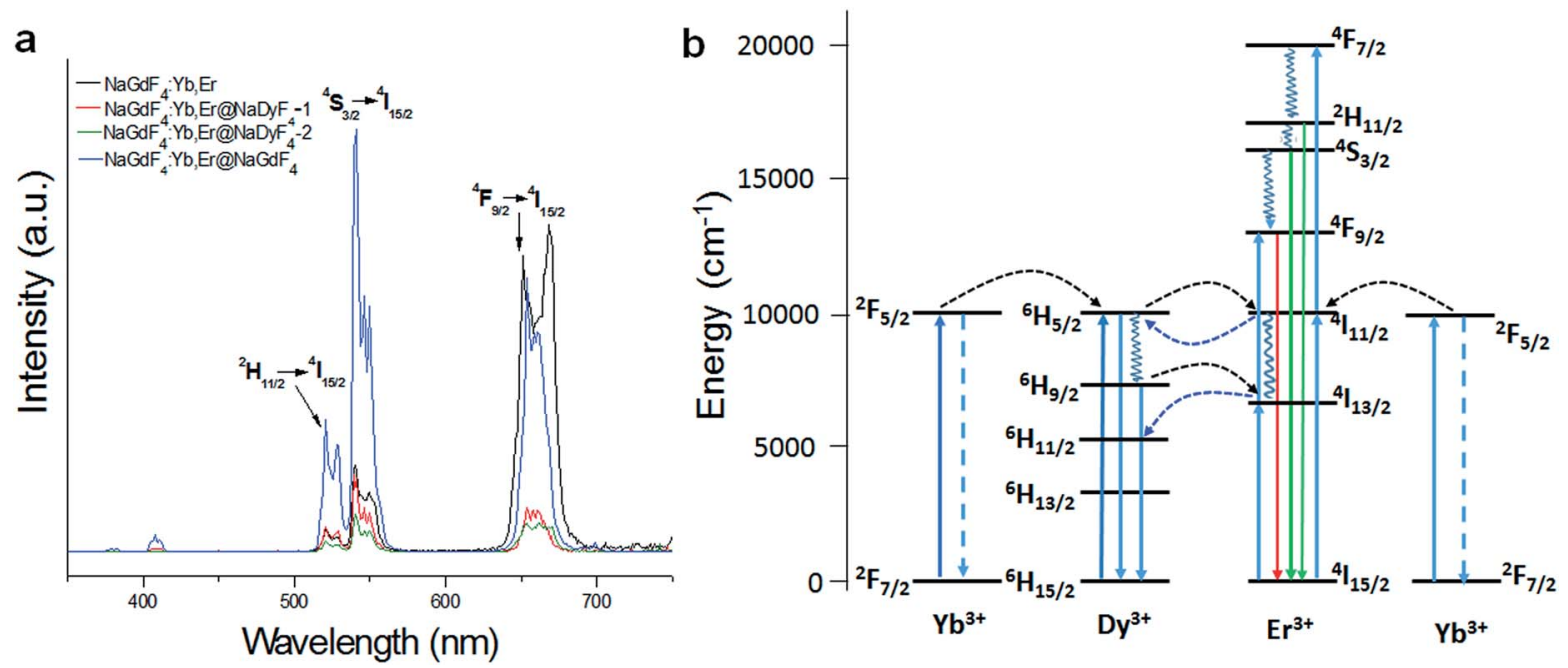

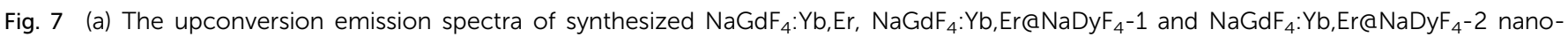
particles under the excitation of $980 \mathrm{~nm}$. (b) The proposed energy transfer mechanism in $\mathrm{NaDyF}_{4}$ coated nanoparticles. 


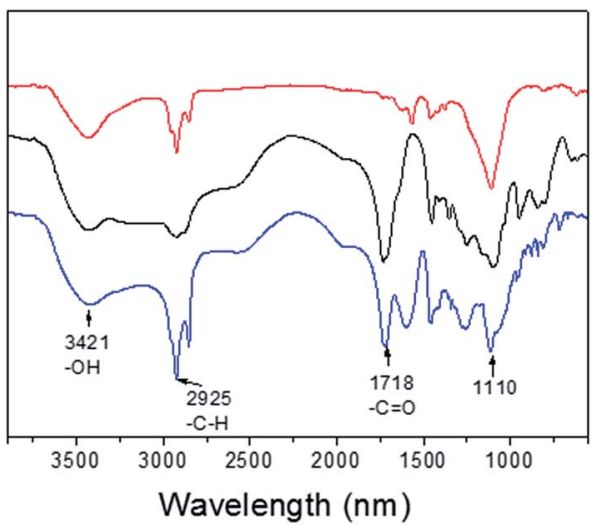

Fig. 8 The responsive Fourier transform infrared spectra (FTIR) of UCNPS-OA (red line), PEG-PAA (black line) and PEG-PAA coated UCNPs (blue line).

state $\left({ }^{4} \mathrm{I}_{15 / 2}\right)$ to the excited state and then to the upper excitation level. Subsequently, a red emission around $660 \mathrm{~nm}$ takes place caused by a radiative transition from the ${ }^{4} \mathrm{~F}_{9 / 2}$ to ${ }^{4} \mathrm{I}_{15 / 2}$ level. Resonance energy transfer has been demonstrated to study the $\mathrm{Dy}^{3+}$ quenching of $\mathrm{Er}^{3+}$ luminescence. $\mathrm{Yb}^{3+}$, as a sensitizer, is excited at $980 \mathrm{~nm}$ from the ground state ${ }^{2} \mathrm{~F}_{7 / 2}$ to the only excitation level ${ }^{2} \mathrm{~F}_{5 / 2}$ then transmits energy to the activator $\mathrm{Er}^{3+} . \mathrm{Yb}^{3+}$ has a much larger absorption cross-section than $\mathrm{Dy}^{3+}, \mathrm{so}^{\mathrm{Yb}^{3+}}$ can offer more energy to $\mathrm{Er}^{3+}$ at this level. Since $\mathrm{NaGdF}_{4}$ :$\mathrm{Yb}, \mathrm{Er} @ \mathrm{NaDyF}_{4} @ \mathrm{NaDyF}_{4}$ has a thicker $\mathrm{NaDyF}_{4}$ layer on the surface of $\mathrm{NaGdF}_{4}: \mathrm{Yb}$,Er, the fluorescence intensity is quite weaker.

The MR contrast performance of $\beta$-NaGdF4:Yb/Er@NaDyF4 nanoparticles with an ultrathin layer

To investigate the MRI performance of the nanoparticles with different shell thicknesses, we conducted relaxivity measurements on a 3.0 T MRI clinical scanner. We measured the gadolinium concentration of PEG-PAA modified $\mathrm{NaGdF}_{4}$ :$\mathrm{Yb}, \mathrm{Er} @ \mathrm{NaDyF}_{4}$ and $\mathrm{NaGdF}_{4}: \mathrm{Yb}, \mathrm{Er} @ \mathrm{NaDyF}_{4} @ \mathrm{NaDyF}_{4}$ by inductively coupled plasma-atomic emission spectrometry (ICPAES). FT-IR has been performed to prove that hydrophobic upconversion core-shell nanoparticles were successfully modified by PEG-PAA in a ligand exchange way. As shown in Fig. 8, two stronger peaks at 1555 and $1456 \mathrm{~cm}^{-1}$ could be observed, corresponding to the asymmetric and symmetric stretching vibration of the $\mathrm{COO}^{-}$group, respectively. After being modified with PEG-PAA, there are two new bands at 1718 and $1110 \mathrm{~cm}^{-1}$, which could be attributed to the stretching vibration of $\mathrm{C}=\mathrm{O}$ and $\mathrm{C}-\mathrm{O}$ of PEG-PAA chains, respectively.

As is well known, paramagnetic $\mathrm{Gd}^{3+}$ ion based materials including $\mathrm{Gd}^{3+}$ ions and chelating ligands are $T_{1}$ (positive) contrast agents. The longitudinal relaxation times $\left(T_{1}\right)$ of different concentrations of PEG-PAA modified nanoparticles in solution were examined by a $3.0 \mathrm{~T}$ clinical MR scanner using a standard inversion recovery sequence. As shown in Fig. 9a, the $T_{1}$ value was significantly reduced with increasing $\mathrm{Gd}^{3+}$ concentration, indicating an obvious enhancement of $T_{1}$ weighted MR contrast. The $r_{1}$ of $\mathrm{NaGdF}_{4}: \mathrm{Yb}, \mathrm{Er} @ \mathrm{NaDyF}_{4}$ nanoparticles with a thin layer is $1.36 \mathrm{mM}^{-1} \mathrm{~s}^{-1}$, which is 2-fold higher than that of $\mathrm{NaGdF}_{4}: \mathrm{Yb}, \mathrm{Er} @ \mathrm{NaDyF}_{4} @ \mathrm{NaDyF}_{4}$ with a thicker shell $\left(0.62 \mathrm{mM}^{-1} \mathrm{~s}^{-1}\right)$, indicating that $\mathrm{NaGdF}_{4}$ :$\mathrm{Yb}, \mathrm{Er} @ \mathrm{NaDyF}_{4}$ is a better $T_{1}$ contrast agent than $\mathrm{NaGdF}_{4}$ :$\mathrm{Yb}, \mathrm{Er} @ \mathrm{NaDyF}_{4} @ \mathrm{NaDyF}_{4}$. In addition, the cytotoxicity of the $\mathrm{NaGdF}_{4}: \mathrm{Yb}$,Er@NaDyF 4 nanoparticle was evaluated by a standard MTT method. As shown in Fig. 9b, the viability of HepG2 cells did not exhibit any reduction after exposure to $\mathrm{NaGdF}_{4}$ :$\mathrm{Yb}, \mathrm{Er} @ \mathrm{NaDyF}_{4}$ nanoparticles for 24 hours, which confirmed their promising cyto-compatibility.

\section{Conclusions}

In conclusion, $\mathrm{NaGdF}_{4}: \mathrm{Yb}, \mathrm{Er}$ coated with different thickness layers of $\mathrm{NaDyF}_{4}$ core-shell nanoparticles have been synthesized successfully by a facile sequential growth process with the low temperature injection of a Dy-OA complex, which had a uniform size and shape. The excitation of the synthesized nanoparticles at $980 \mathrm{~nm}$ showed an obvious luminescence quenching arising out of energy migration-mediated upconversion. Furthermore, ultrathin $\mathrm{NaDyF}_{4}$ shell coating remained the $T_{1}$-weighted $\mathrm{MR}$ imaging performance of $\mathrm{NaGdF}_{4}: \mathrm{Yb}, \mathrm{Er}$.
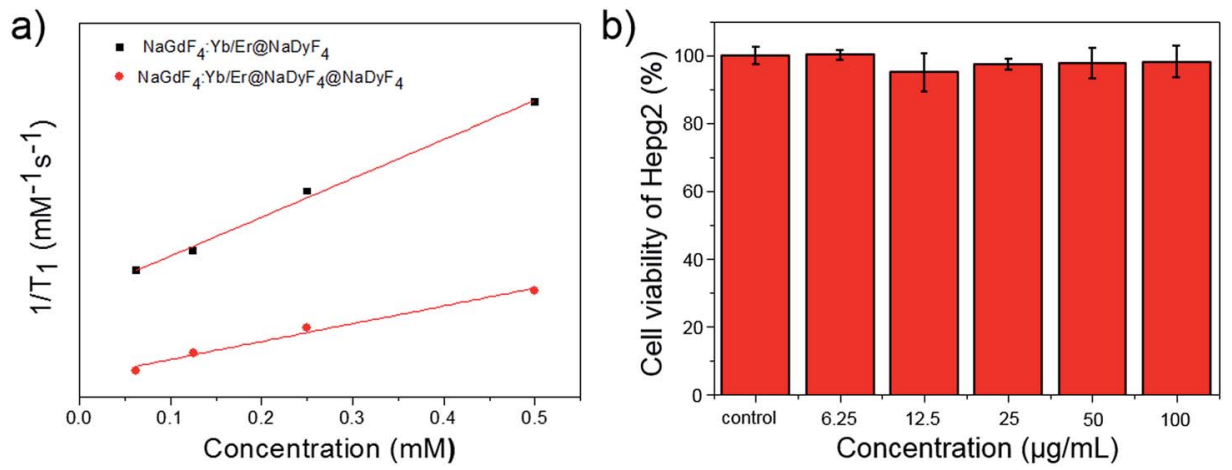

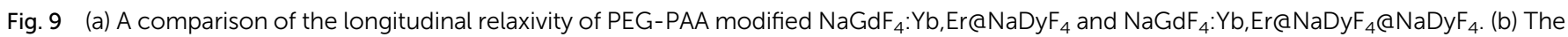
cyto-compatibility result of PEG-PAA modified $\mathrm{NaGdF}_{4}$ :Yb,Er@NaDyF 4 on $\mathrm{HepG} 2$ cells. 


\section{Conflicts of interest}

There are no conflicts to declare.

\section{Acknowledgements}

We acknowledge the funding support from the National Natural Science Foundation of China (Grant 21471043, 51572067, 21501039 and 51702309), the Major/Innovative Program of Development Foundation of Hefei Center for Physical Science and Technology (No. 2016FXZY005), and the Natural Science Foundation of Anhui Province of China (1708085ME114). Y. Su and L. Hao contributed equally.

\section{References}

1 H. C. Hu, J. J. Liu, J. Q. Yu, X. C. Wang, H. W. Zheng, Y. Xu, M. Chen, J. Han, Z. Liu and Q. Zhang, Nanoscale, 2017, 9, 4826-4834.

2 X. Zhang, Y. Zhao, X. Jia, Y. Zhao, L. Shang, Q. Wang, G. I. N. Waterhouse, L. Z. Wu, C. H. Tung and T. Zhang, Adv. Energy Mater., 2018, 1702780.

3 A. M. El-Toni, M. A. Habila, J. P. Labis, Z. A. ALOthman, M. Alhoshan, A. A. Elzatahry and F. Zhang, Nanoscale, 2016, 8, 2510-2531.

4 R. G. Chaudhuri and S. Paria, Chem. Rev., 2012, 112, 2373-2433.

5 G. Y. Chen, H. L. Qiu, P. N. Prasad and X. Y. Chen, Chem. Rev., 2014, 114, 5161-5214.

6 H. Dong, S. R. Du, X. Y. Zheng, G. M. Lyu, L. D. Sun, L. D. Li, P. Z. Zhang, C. Zhang and C. H. Yan, Chem. Rev., 2015, 115, 10725-10815.

7 N. M. Idris, M. K. G. Jayakumar, A. Bansal and Y. Zhang, Chem. Soc. Rev., 2015, 44, 1449-1478.

8 J. J. Li, F. F. Cheng, H. P. Huang, L. L. Li and J. J. Zhu, Chem. Soc. Rev., 2015, 44, 7855-7880.

9 X. M. Li, F. Zhang and D. Y. Zhao, Nano Today, 2013, 8, 643-676.

10 J. Zhou, Z. Liu and F. Y. Li, Chem. Soc. Rev., 2012, 41, 1323-1349.

11 G. Y. Chen, I. Roy, C. H. Yang and P. N. Prasad, Chem. Rev., 2016, 116, 2826-2885.

12 X. Y. Huang, S. Y. Han, W. Huang and X. G. Liu, Chem. Soc. Rev., 2013, 42, 173-201.

13 M. H. Li, Z. J. Zheng, Y. Q. Zheng, C. Cui, C. X. Li and Z. Q. Li, ACS Appl. Mater. Interfaces, 2017, 9, 2899-2905.

14 M. J. Tou, Y. Y. Mei, S. Bai, Z. G. Luo, Y. Zhang and Z. Q. Li, Nanoscale, 2016, 8, 553-562.

15 C. Cui, M. J. Tou, M. H. Li, Z. G. Luo, L. B. Xiao, S. Bai and Z. Q. Li, Inorg. Chem., 2017, 56, 2328-2336.

16 X. Y. Huang, J. Mater. Sci., 2016, 51, 3490-3499.

17 X. Y. Huang, Opt. Lett., 2015, 40, 3599-3602.

18 C. H. Dong, A. Korinek, B. Blasiak, B. Tomanek and F. C. J. M. van Veggel, Chem. Mater., 2012, 24, 1297-1305.

19 K. A. Abel, J.-C. Boye, C. M. Andrei and F. C. J. M. van Veggel, Chem. Lett., 2011, 2, 185-189.

20 X. M. Li, D. K. Shen, J. P. Yang, C. Yao, R. C. Che, F. Zhang and D. Y. Zhao, Chem. Mater., 2013, 25, 106-112.

21 H. S. Qian and Y. Zhang, Langmuir, 2008, 24, 12123-12125.
22 B. Xu, X. Zhang, W. Huang, Y. Yang, Y. Ma, Z. Gu, T. Zhai and Y. Zhao, J. Mater. Chem. B, 2016, 4, 2776-2784.

23 H. Q. Wen, H. Y. Peng, K. Liu, M. H. Bian, Y. J. Xu, L. Dong, X. Yan, W. P. Xu, W. Tao, J. L. Shen, Y. Lu and H. S. Qian, ACS Appl. Mater. Interfaces, 2017, 9, 9226-9232.

24 E. Boros, E. M. Gale and P. Caravan, Dalton Trans., 2015, 44, 4804-4818.

25 F. Auzel, Chem. Rev., 2004, 104, 139-174.

26 K. Z. Zheng, Z. Y. Liu, C. J. Lv and W. P. Qin, J. Mater. Chem. $C, 2013,1,5502-5507$.

27 G. T. Tian, W. Y. Yin, J. J. Jin, X. Zhang, G. M. Xing, S. J. Li, Z. J. Gu and Y. L. Zhao, J. Mater. Chem. B, 2014, 2, 1379-1385. 28 S. Biju, M. Harris and L. V. Elst, RSC Adv., 2016, 6, 61443-61448. 29 F. Fan, Y. Yu, F. Zhong, M. Gao, T. Sun, J. Liu, H. Zhang, H. Qian, W. Tao and X. Yang, Theranostics, 2017, 7, 1290-1302. 30 B. R. Smith and S. S. Gambhir, Chem. Rev., 2017, 117, 901-986. 31 K. Luo, G. Liu, W. C. She, Q. Y. Wang, G. Wang, B. He, H. Ai, Q. Gong, B. Song and Z. Gu, Biomaterials, 2011, 32, 79517960.

32 R. R. Qiao, H. Y. Qiao, Y. Zhang, Y. B. Wang, C. W. Chi, J. Tian, L. Zhang, F. Cao and M. Gao, ACS Nano, 2017, 11, 1816-1825.

33 Z. J. Zhou, C. Q. Wu, H. Y. Liu, X. L. Zhu, Z. H. Zhao, L. R. Wang, Y. Xu, H. Ai and J. Gao, ACS Nano, 2015, 9, 3012-3022.

34 D. Ling, N. Lee and T. Hyeon, Acc. Chem. Res., 2015, 48, 12761285.

35 S. Laurent, E. L. Vander, F. Copoix and R. N. Muller, Invest. Radiol., 2001, 36, 115-122.

36 S. Laurent, E. L. Vander, C. Henoumont and R. N. Muller, Contrast Media Mol. Imaging, 2010, 5, 305-308.

37 The ESUR Contrast Media Safety Committee (CMSC) Contrast Medium Guidelines, Version 9.0, The European Society of Urogenital Radiology, 2015.

38 ACR Manual on Contrast Media, Version 10.1, American College of Radiology (ACR) Committee, 2015.

39 H. Y. Xing, S. J. Zhang, W. B. Bu, X. P. Zheng, L. J. Wang, Q. F. Xiao, D. Ni, J. Zhang, L. Zhou, W. Peng, K. Zhao, Y. Hua and J. Shi, Adv. Mater., 2014, 26, 3867-3872.

40 N. J. J. Johnson, W. Oakden, G. J. Stanisz, R. S. Prosser and F. C. J. M. van Veggel, Chem. Mater., 2011, 23, 3714-3722.

41 J. Wang, H. Zhang, D. L. Ni, W. P. Fan, J. X. Qu, Y. Y. Liu, Y. Jin, Z. Cui, T. Xu, Y. Wu, W. Bu and Z. Yao, Small, 2016, 12, 3591-3600.

42 D. L. Ni, Z. W. Shen, J. W. Zhang, C. Zhang, R. H. Wu, J. A. Liu, M. Yi, J. Wang, Z. Yao, W. Bu and J. Shi, ACS Nano, 2016, 10, 3783-3790.

43 B. B. Ding, K. Liu, F. Zhang, Y. Wang, S. Cheng, Y. Lu and H. S. Qian, CrystEngComm, 2015, 17, 5900-5905.

44 Z. Q. Li, Y. Zhang and S. Jiang, Adv. Mater., 2008, 20, 47654769.

45 Y. Zhang, G. K. Das, V. Vijayaragavan and Q. C. Xu, Nanoscale, 2014, 6, 12609-12617.

46 Y. Seki and Y. Furukawa, Jpn. J. Appl. Phys., 1971, 10, 891897.

47 V. Mahalingam, R. Naccache, F. Vetrone and J. A. Capobianco, Chem. Commun., 2011, 47, 3481-3483. 